\title{
THE EARLY POST-NATAL DEVELOPMENT OF THE NEURONAL LYSOSOME ${ }^{1}$
}

\author{
V. Idoyaga-Vargas, ${ }^{2}$ Josephine C. Santiago, Patricia D. Petiet \\ and O. Z. SelLINGER ${ }^{3}$ \\ Mental Health Research Institute, The University of Michigan Medical Center, \\ Ann Arbor, MI 48104, U.S.A.
}

(Received 18 April 1972. Accepted 13 June 1972)

\begin{abstract}
The hydrolysis of $p$-nitrophenyl-2-acetamido-2-deoxy- $\beta$-D-gluco-(I) and $\beta$-Dgalacto-pyranoside (II) and of $p$-nitrophenyl- $\alpha$-D-mannopyranoside (III) by neuronal cell bodies and glial cells isolated from the cerebral cortex of 18-day-old or adult rats was found to be equally efficient, with relative ratios of hydrolysis for I, II and III of approximately $10: 1: 0.5$ in both cell types and at both ages. Homogenates of the neuronal cell bodies obtained from cerebral cortices of 3-, 8-, 12-, 18- and 32-day-old rats were subjected to differential centrifugation and the subcellular localization of $N$-acetyl- $\beta$-D-glucosaminidase (EC 3.2.1.30) [hydrolysing (I)] was compared to that of the mitochondrial marker, succinate-INToxidoreductase (EC 1.3.99.1). A fraction in which $N$-acetyl- $\beta$-D-glucosaminidase exhibited maximal specific activity could be isolated at all ages, an observation indicating that the potential for active hydrolytic performance is incorporated into the neuronal lysosome very early post-natally. The specific activities of $N$-acetyl- $\beta$-D-glucosaminidase and succinateINT-oxidoreductase reached their respective maxima at widely different times postnatally: at 10-12 days for the mitochondrial enzyme and at about 18 days for the glycosidase, a difference suggesting that in the cortical neuron lysosomes and mitochondria develop out of step. The mitochondrial, lysosomal and microsomal fractions obtained by differential centrifugation were subjected to equilibrium density centrifugation and the presence of two populations of $N$-acetyl- $\beta$-D-glucosaminidase-bearing particles was demonstrated. Although their presence was readily apparent in the neurons from 8- and 12-day old brains, it was difficult to discern their presence in the neurons from the 3- and the 18-day-old brains. In 8 -day-old brains gradient fractions obtained from neurons containing $N$-acetyl- $\beta$-Dglucosaminidase of a specific activity up to 8-fold higher than that of the enzyme in the original neuronal homogenate were examined by electron microscopy and the concentration of numerous lysosomes and derivative bodies in these fractions was verified. Our present study demonstrates the capability of the immature and developing neuron to tightly couple the pace of its degradative processes to that of its highly efficient and highly selective synthetic activities.
\end{abstract}

$N$-ACETYL- $\beta$-D-GLUCOSAMINIDASE (EC $3.2 .1 .30 ; \beta$-2-acetylamino-2-deoxy-D-glucoside acetylaminodeoxyglucohydrolase) is localized in the lysosomes of the cerebral cortex of the rat (Sellinger, Rucker and De Balbian Verster, 1964) and the guinea pig (BOSMANN and HEMSWORTH, 1970), as well as in the lysosomes of several other anatomical areas of the rat brain (SEllinger and HiatT, 1968; SELlinger and Nordrum, 1969; Sellinger, Nordrum and Idoyaga-Vargas, 1971b). Tallman, Brady and SUZUKI (1971) recently demonstrated the lysosomal localization of this hydrolase in

${ }^{1}$ This work was supported by grant NS-06294 and training grant MH 07147 from the United States Public Health Service.

2 Post-doctoral trainee; present address: Oak Ridge National Laboratories, Division of Biology, Oak Ridge, TN, U.S.A.

${ }^{3}$ To whom reprint requests should be addressed.

Abbreviations used: INT, 2-(p-iodophenyl)-3-(p-nitrophenyl)-5-phenyl-tetrazolium chloride; LY, lysosomal fraction; MIC, microsomal fraction; MIT, mitochondrial fraction. 
the human brain. In the past few years, several workers (SANDHOFF, 1969; OKADA and O'Brien, 1969; Young, Ellis, LaKe and PATrick, 1970; HARzer, 1970; SUzUKI and SuzUKI, 1970; SuzUKI et al., 1971 ; HARzer and SANdHofF, 1971; PATEL and KoENIG, 1971 ) noted the presence of two distinct forms of $N$-acetyl- $\beta$-D-glucosaminidase in normal cerebral tissue, a finding originally reported for the splenic enzyme by RoBINSON and STIRLING (1967).

Recently, we reported the development of a bulk-separation procedure which yields highly purified neuronal cell bodies and intact glial cells from gram amounts of brain tissue (SELLINGER et al., 1971a) and its use, inter alia, in the characterization of the neuronal and glial $N$-acetyl- $\beta$-D-glucosaminidase and $\alpha$-D-mannoside mannohydrolase ( $\alpha$-mannosidase; EC 3.2.1.24) (IDOYAGA-VARGAS and SELlinger, 1971 ; SELlinger et al., 1971d). These preliminary findings have been extended in the present study which also provides data on the development of the neuronal and glial glycosidases, together with evidence of a heterogeneity of form accompanying the development of the organelle containing these enzymatic activities in situ, i.e. the nerve cell lysosome. A study of the development of the two distinct molecular forms of neuronal $N$-acety]- $\beta$-D-glucosaminidase and additional information on age-dependent differences in their structural latency, their properties and the nature of their molecular interrelationship will be reported elsewhere (Sellinger, Santiago, Sands and SLOAT, in preparation).

\section{EXPERIMENTAL PROCEDURE}

Male Sprague-Dawley rats were used. $p$-Nitrophenyl-2-acetamide-2-deoxy- $\beta$-D-gluco- and $\beta$-D-galacto-pyranosides and $p$-nitrophenyl-a-D-mannopyranoside were purchased from Pierce Chemical Co. (Rockford, Ill.); polyvinylpyrrolidone (nominal average molecular weight: 40,000; Plasdone C) was obtained from General Aniline \& Film Co. (Calvert City, Kentucky), and bovine serum albumin (Fraction V) was from Miles Laboratories (Kankakee, Ill.). INT [2-( $p$-iodophenyl)-3( $p$-nitrophenyl)-5-phenyl-tetrazolium chloride] was purchased from Sigma Chemical Co. (St. Louis, Mo.). Sucrose (enzyme grade) was obtained from Schwarz-Mann (Orangeburg, N.Y.). All other reagents were of the best available analytical grade.

Protein was determined according to Lowry, Rosebrough, FARr and RANDALl (1951), with crystalline bovine serum albumin as standard, and RNA was determined by the procedure of FLECK and BEGG (1965).

The procedure of Sellinger et al. (1971a), described in somewhat more detail by Johnson and SELlinger (1971), was used for the preparation of the neuronal cell bodies and glial cells. The neuronal cell bodies were homogenized in $0.25 \mathrm{M}$ sucrose with 3 up-and-down strokes of a Potter-Elvehjem glass-Teflon homogenizer rotating at about $1300 \mathrm{rev} / \mathrm{min}$, and the homogenate was subjected to differential centrifugation as described by SELlinger and De Balbian VersTer (1962). In this procedure, the postmitochondrial supernatant fraction is centrifuged at $10,000 \mathrm{~g}$ for $15 \mathrm{~min}$ (Spinco rotor 65 ) and the sediment is washed once by resuspension and centrifugation at $10,000 \mathrm{~g}$ for $12 \mathrm{~min}$ to yield the fraction termed lysosomal (SELLINGER et al., 1964). The supernatant fluid remaining after this centrifugation step is spun at $102,000 \mathrm{~g}$ for $60 \mathrm{~min}$ and the microsomal and soluble cell sap fractions are obtained as a pellet and a supernatant fluid respectively. Suspensions $(1.5 \mathrm{ml})$ in $0.25 \mathrm{M}$ sucrose of the mitochondrial, lysosomal and microsomal fractions were layered on top of $10 \mathrm{ml}$ of linear sucrose gradients $(35-60 \%, \mathrm{w} / \mathrm{v})$ prepared in cellulose nitrate tubes which were then centrifuged in the Spinco SW-41 rotor at $49,000 \mathrm{~g}$ for $14.5 \mathrm{~h}$. Collection of the tube contents was as described previously, with continuous monitoring of the optical density of the effluent at $280 \mathrm{~nm}$ (SELLINGER et al., 1971c).

The assay of $N$-acetyl- $\beta$-D-glucosaminidase was as previously described (SELLINGER et al., 1964); hydrolytic activity was also measured using $p$-nitrophenyl- $N$-acetyl- $\beta$-D-galactosaminide as substrate. $a$-Mannosidase activity was assayed using $p$-nitrophenyl- $\alpha-D-$ mannopyranoside as substrate. Separate optimal conditions were established for the measurement of the neuronal and the glial hydrolases, as follows: hydrolyses of the glucosaminide, galactosaminide and mannoside by the neurons and their subfractions were carried out with $4 \cdot 8,3 \cdot 2$ and $20 \cdot 2 \mathrm{~mm}$ substrate, respectively, whereas for the hydrolysis by glia, the concentrations of these substrates were $12 \cdot 8,5 \cdot 3$ and $25 \cdot 2 \mathrm{~mm}$, respectively. The 
optimal $\mathrm{pH}$ values for the hydrolyses were $\mathrm{pH} 4 \cdot 1$ for the glycosaminides and $\mathrm{pH} 5.0$ for the mannoside. In all assays, a citrate-phosphate buffer adjusted to a constant ionic strength of $\Gamma=0.5$ was used (Elving, MARKowITZ and ROSENTHAL, 1956). Incubations in a final volume of $0.93 \mathrm{ml}$ were at $37^{\circ} \mathrm{C}$ for the periods of time specified in the legends. Linearity of colour development at $412 \mathrm{~nm}$ as a function of time and enzyme concentration was observed under all assay conditions. Succinate-INToxidoreductase (EC 1.3.99.1), a mitochondrial marker in the cerebrum (HUNTER and MrLLSON, 1966), as well as in the cerebellar, granular and molecular layers (SELLINGER, LodIN and AzCURRA, 1972) was assayed as previously described (SELLINGER and HIATT, 1968). Unless otherwise specified, a unit of hydrolase activity refers to the number of $\mu$ moles of $p$-nitrophenol liberated/h and the specific activity refers to the number of units/mg of protein. The unit of succinate-INT-oxidoreductase is arbitrary and refers to the absorbance at $490 \mathrm{~nm} / \mathrm{ml}$, with specific activity in units/ $\mathrm{mg}$ of protein.

The techniques previously described by JoHNSON and SELLINGER (1971) were used for the preparation and electron microscopic examination of the specimens.

\section{RESULTS}

The hydrolysis of the glycosaminide and the mannoside substrates by the neuronal and glial cell preparations was determined at the optimal $\mathrm{pH}$ values for each substrate and under optimal conditions (see Methods) for colour development; subsequently, the dependence of the hydrolysis as a function of the concentration of the substrate was also established. The results of these experiments permitted the calculation of apparent $K_{m}$ values which were, respectively, $0.29,0.39$ and $10.9 \mathrm{~mm}$ for the neuronal and $0.96,0.80$ and $7.6 \mathrm{~mm}$ for the glial hydrolysis of the glycosaminide, the galactosaminide and the mannoside. The inhibition of the hydrolysis of glycosaminide or galactosaminide by acetate was greater for the neuronal than for the glial preparation (Fig. 1). The calculated apparent $K_{t}$ values with glycosaminde as substrate were $5.0 \mathrm{~mm}$ for the neuronal and $15.0 \mathrm{~mm}$ for the glial $N$-acetyl- $\beta$-D-glucosaminidase. The inhibition of the neuronal $N$-acetyl- $\beta$-D-glucosaminidase by $N$-acetyl glucosamine ( $50 \mathrm{~mm}$ ) was also about 30 per cent greater than that of the glial enzyme.

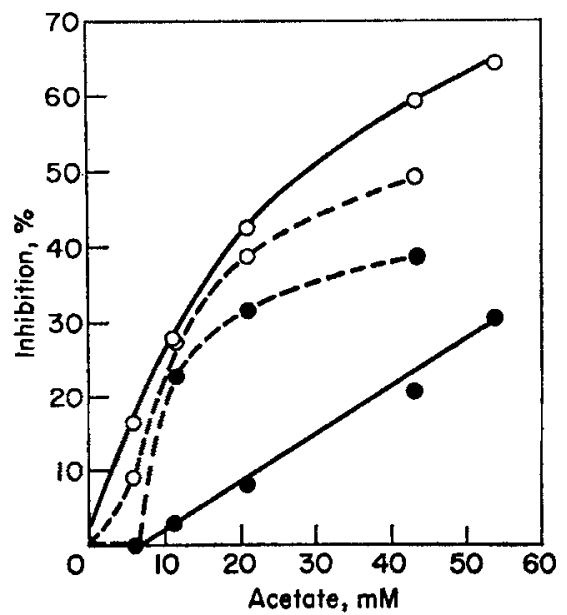

FIG. 1.-The inhibitory effect of acetate on the activity of glycosaminidases in cells from 18-day-old rat brains. Incubations were carried out, as described in Experimental Procedure, for $60 \mathrm{~min}$ for the neuronal and for $300 \mathrm{~min}$ for the glial preparations. The concentration of acetate ( $\mathrm{Na}$ salt) varied as indicated. Substrates: $p$-nitrophenyl- $N$-acetyl$\beta$-D-glucosaminide $(--) ; p$-nitrophenyl- $N$-acetyl- $\beta$-D-galactosaminide: $(---)$; cells: neuronal cell bodies $(O)$; glial cells $(\Theta)$. 


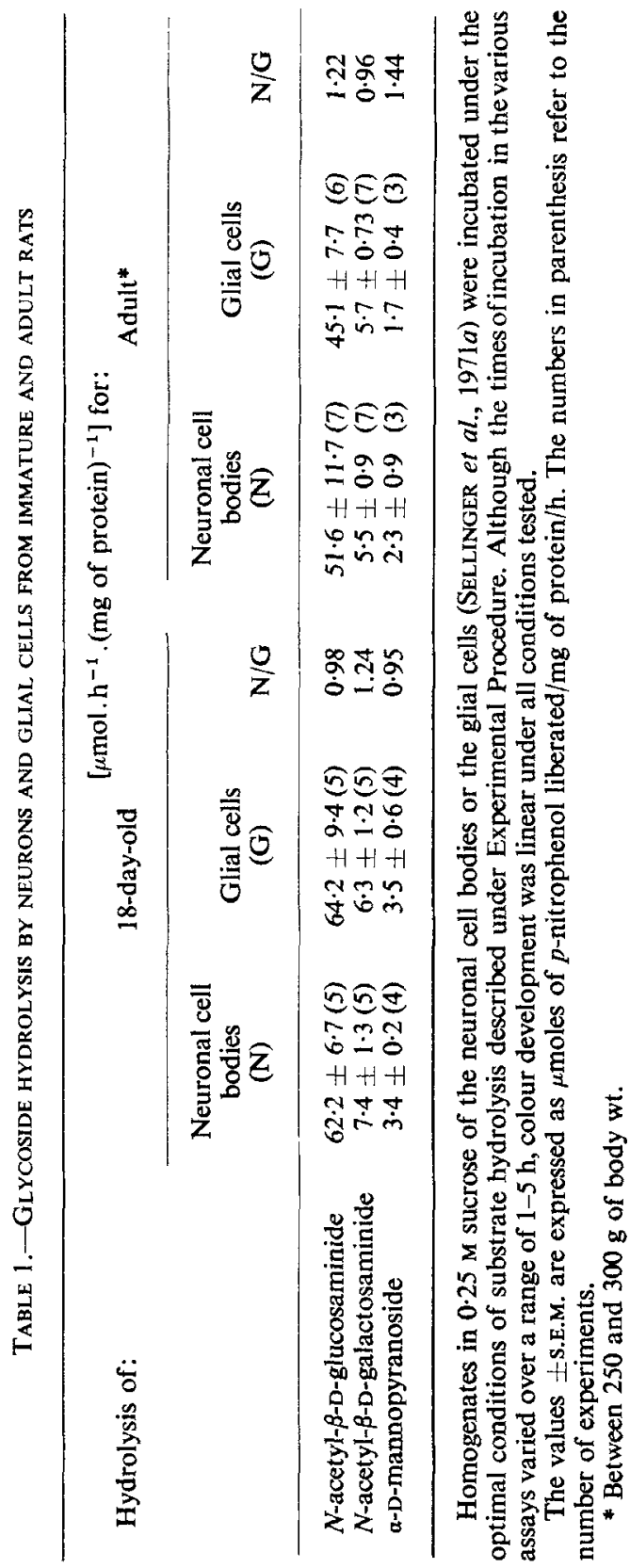




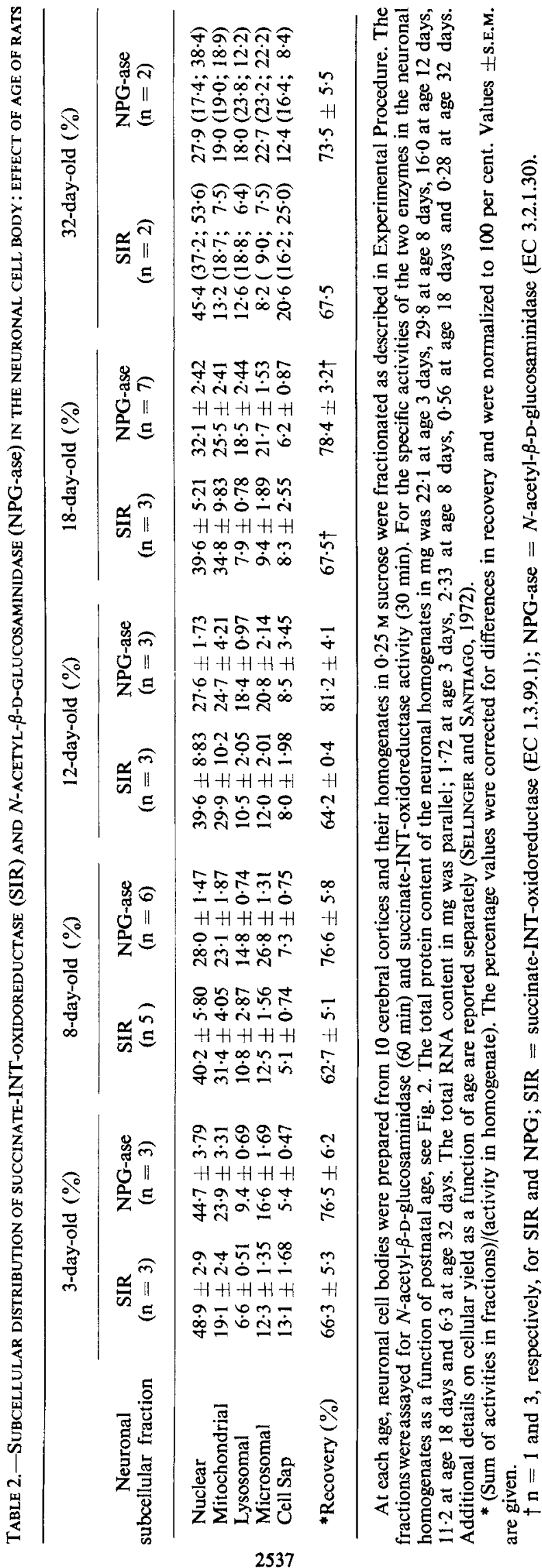


The post-natal development of the neuronal and glial glycosidases. The specific activities and their ratios between the neuronal and the glial glycosidases were determined at 18 days post-natally and in the adult rat (Table 1). Hydrolysis of the glucosaminide was about 10 -fold more rapid than the hydrolysis of the galactosaminide, which in turn was hydrolysed at a rate about double that of the mannoside. Most of the ratios measuring neuronal vs. glial hydrolytic effectiveness were rather close to unity indicating that both cell types are endowed with the same capacity in this respect.

Because of an insufficient amount of glial cells available, the developmental profile of the intracellular distribution of $N$-acetyl- $\beta$-D-glucosaminide was investigated only in the neuronal cell bodies which were isolated from cerebral cortices of 3-, 8-, 12-, 18- and 32-day-old rats. For comparison, the developmental profile of the intracellular distribution of the mitochondrial marker enzyme, succinate-INT-oxidoreductase (SELLINGer et al., 1971b) was also determined. The changes in intracellular distribution and in the specific activities of the two enzymes were examined as a function of postnatal age (Table 2 and Fig. 2). There was a significant age-dependent shift in the
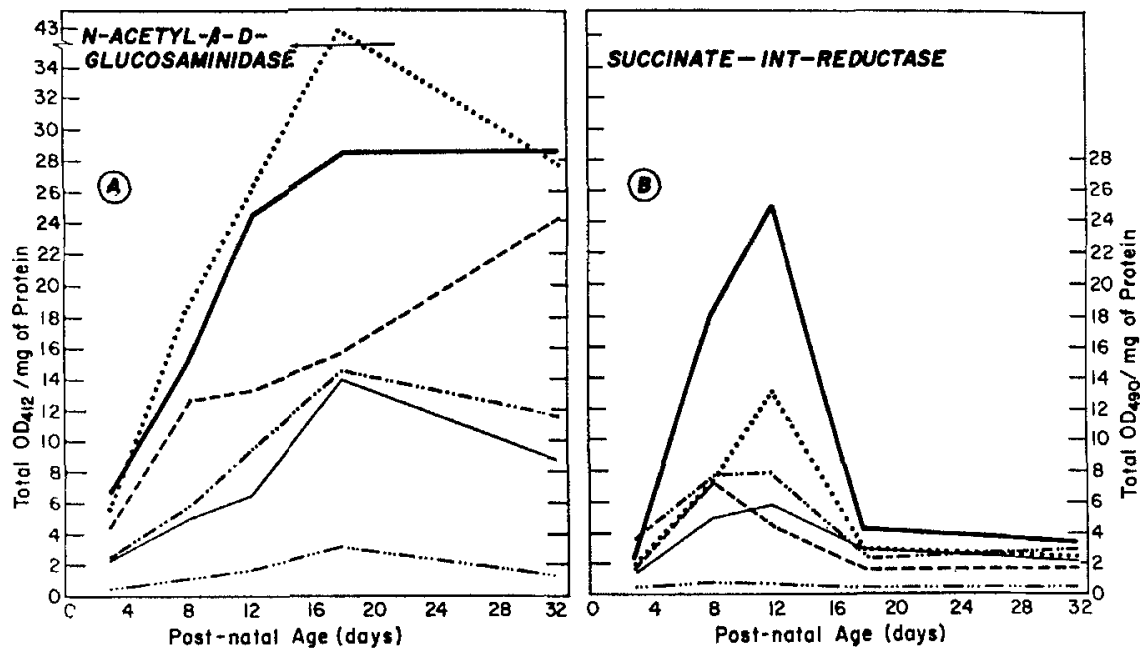

FIG. 2.-The early post-natal development of neuronal $N$-acetyl- $\beta$-D-glucosaminidase (A) and succinate-INT-oxidoreductase (B). Neuronal cell bodies were prepared from groups of 10 cerebral cortices of 3-, 8-, 12-, 18- and 32-day-old rats, and the homogenates in $0.25 \mathrm{M}$ sucrose were fractionated as described in Experimental Procedure. The ordinates refer to the specific activities expressed as total o.D. of the fraction/mg of protein. Incubations of the fractions were for $60 \mathrm{~min}$ in (A) and $30 \mathrm{~min}$ in (B). ( - . - ) homogenate; (- nuclear fraction; (- $(-)$ mitochondrial fraction; $(\cdots \cdots)$ lysosomal fraction; (- --$)$ microsomal fraction; (_...-) soluble cell sap fraction.

percentage of $N$-acetyl- $\beta$-D-glucosaminidase sedimenting into the lysosomal fraction, from a low value of 9.4 per cent at age 3 days to a rather constant value of 18 per cent from age 12 onward (Table 2). Correspondingly, the percentage of the glycosidase contaminating the nuclear fraction decreased from about 45 to about 30 per cent. The $N$-acetyl- $\beta$-D-glucosaminidase content in the mitochondrial fraction remained rather uniform (about 23 per cent) over the entire time period examined, whereas that of the microsomal fraction rose from 16.6 to 26.8 per cent between days 3 and 8 , 
but stabilized subsequently at about 20 per cent. The data indicate a much lesser degree of age-dependent shifting of the intracellular location of the mitochondrial succinate-INT-oxidoreductase since throughout the time span examined (with the possible exception of the situation at age 32 days) no less than 70 per cent of the total recovered activity was shared by the nuclear and mitochondrial fractions. Although the recovery of the mitochondrial succinate-INT-oxidoreductase was not as good as that of the $N$-acetyl- $\beta$-D-glucosaminidase, this circumstance could not, in our estimation, account for the age dependent differences displayed by the intracellular distributions of the two enzymes.

Although both enzymes exhibited sharp increases of specific activity in the early post-natal period, they reached their respective maxima at widely different times: 10-12 days post-natally for succinate-INT-oxidoreductase and about 1 week later (around 18 days) for $N$-acetyl- $\beta$-D-glucosaminidase (Fig. 2). Although the differences in the development of the two enzymes were readily noticeable by inspection of any fraction, they were particularly marked in the mitochondrial and lysosomal fractions (Fig, 2). The developmental profiles of the two enzymes in the microsomal fraction also differed drastically, since the specific activity of succinate-INT-oxidoreductase in this fraction decreased abruptly from day 8 onward, whereas that of $N$-acetyl- $\beta$-Dglucosaminidase continued to increase up to day 32.

Lysosomal heterogeneity in the immature nerve cell body. In view of the rather conspicuous shifts with age of the intracellular distribution of lysosomal $N$-acetyl- $\beta$-Dglucosaminidase (Table 2) and because of the unequal patterns of development of this hydrolase and of the mitochondrial succinate-INT-oxidoreductase (Fig. 2), the mitochondrial, lysosomal and microsomal fractions obtained from neuronal cell bodies on post-natal days $3,8,12$ and 18 were subjected to equilibrium density centrifugation on linear gradients of sucrose. These experiments revealed a pattern of age-dependent heterogeneity among the lysosomes sedimenting into the three fractions; they also led to the identification in the 8-day old neuronal cell bodies of two populations of lysosomes, each highly enriched in $N$-acetyl- $\beta$-D-glucosaminidase.

The gradient profiles of $N$-acetyl- $\beta$-D-glucosaminidase and of the absorbance at $280 \mathrm{~nm}$ of fractions MIT, LY and MIC are illustrated in Fig. 3. The panels in rows A, B and $C$ show the development of the enzyme in the mitochondrial(MIT), lysosomal(LY) and microsomal (MIC) fractions, respectively, of the neuronal cell bodies from the brains of 3- to 18-day-old rats, while columns 1-4 show the age-dependent profile of the enzyme activity in the 3 subcellular fractions. Since the absorbance at $280 \mathrm{~nm}$ reflects the considerable amounts of ribosomal RNA present in virtually every fraction (see panel B 2, Fig. 3, as an example of the gradient distribution of RNA in one of the fractions LY), the $280 \mathrm{~nm}$ absorbance could not be used to determine the actual specific activity profile of $N$-acetyl- $\beta$-D-glucosaminidase in the gradient. The profiles shown in Fig. 3 illustrate the presence of at least two populations of $\mathrm{N}$-acetyl$\beta$-D-glucosaminidase-bearing particles, one sedimenting in tube 7 or 8 and the other one appearing as a shoulder or a distinct activity peak between tubes 10 and 12 . This bimodal gradient distribution of particulate $N$-acetyl- $\beta$-D-glucosaminidase was most apparent when fraction LY was used, less obvious with fraction MIT, and discernible only with difficulty for fraction MIC. However, in the 3-day-old neuron fraction LY (panel 1 B) failed to clearly display such a heterogeneity, but fraction MIT did (panel 1 A). These findings were consistent with those in Table 1, showing 23.9 per 
(1)
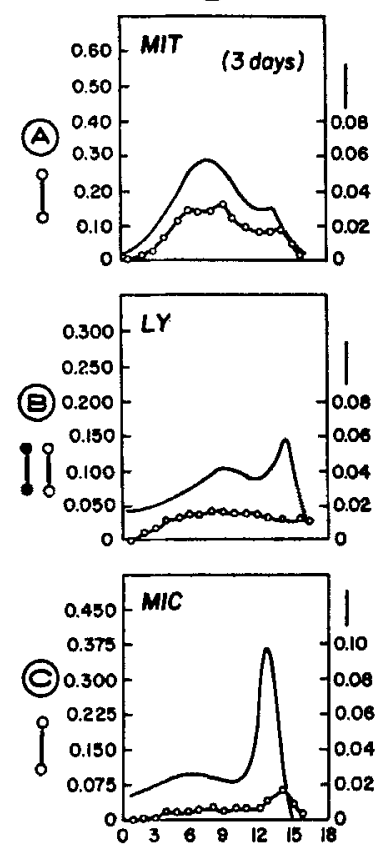

(2)

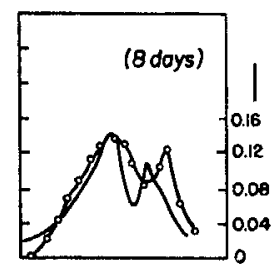

(3)
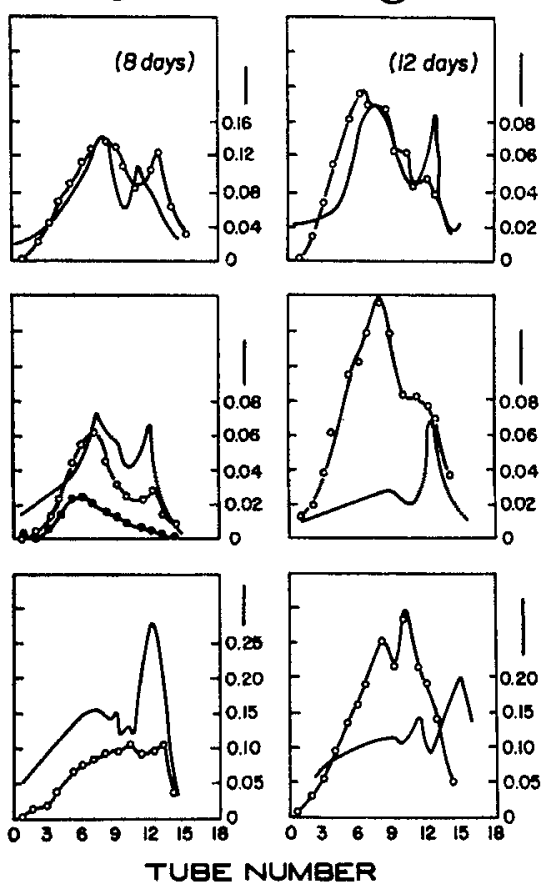
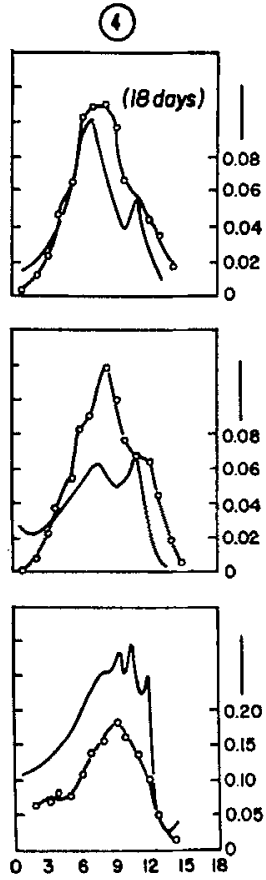

FIG, 3. - Gradient distribution profiles of $N$-acetyl - $\beta$-D-glucosaminidase and protein of the mitochondrial (MIT), lysosomal (LY) and microsomal (MIC) fractions obtained from 3-, 8-, 12- and 18-day-old neuronal cell bodies. The primary fractions were suspended in $0.25 \mathrm{M}$ sucrose and were centrifuged in a gradient, as described in Experimental Procedure. (O—O) $N$-acetyl- $\beta$-D-glucosaminidase activity expressed as O.D.412/h/ tube; ( $\longrightarrow$ protein, expressed as the 0.D.280 of the gradient effluent monitored continuously by the Uvicord system (SELLINGER et al., 1971c) and (-—) RNA, expressed as O.D.260/tube (FLECK and BEGG, 1965).

cent of the total $N$-acetyl- $\beta$-D-glucosaminidase of the 3-day-old neuron in fraction MIT and only 9.4 per cent in fraction LY.

To evaluate the fine density differences between the populations of neuronal lysosomes suggested by the profiles of Fig. 3, several experiments were carried out in which the specific activity of $N$-acetyl- $\beta$-D-glucosaminidase was assessed by determining the protein content of each effluent tube. The presence of two peaks of $\mathrm{N}$-acetyl$\beta$-D-glucosaminidase specific activity [enriched, depending on the age of the animal, up to 15 -fold over the immediate parent preparation (SELlinger, SANTIAGo, SANDS and SLOAT, in preparation)], with virtually the same location in the gradient irrespective of whether fraction MIT or fraction LY were used, is illustrated in Fig. 4.

The morphological appearance (Fig. 5) of the contents of tubes 3 and 6 of fraction MIT (Fig. 4, left panel) and of tubes 4 and 6 of fraction LY (Fig. 4, right panel) indicated the presence in both of numerous lysosomal bodies admixed with membranous elements of the smooth and rough endoplasmic reticulum (Fig. 5, A and C). Structures identifiable as mitochondrial remnants were also evident, particularly in the less dense zone of the gradient (Fig. 4, peak B; and Fig. 5, B and D). The greatest 

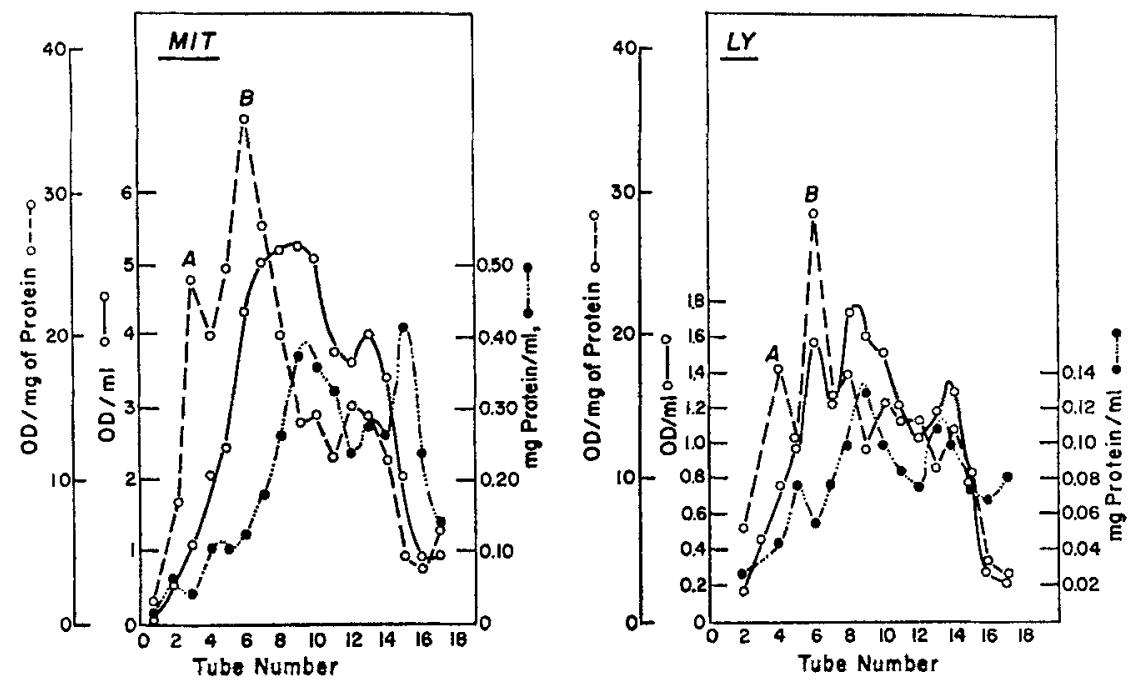

FIG. 4.-The gradient profile of the specific activity of $N$-acetyl- $\beta$-D-glucosaminidase. Suspensions of the mitochondrial (MIT) and lysosomal (LY) fractions (see Experimental Procedure) were centrifuged on a gradient, as described in Experimental Procedure, and the activity of $N$-acetyl- $\beta$-D-glucosaminidase was determined in each tube (o.D. $/ \mathrm{ml}$, $\mathrm{O}-\mathrm{O}$ ). Protein was also determined in each tube (LowRY et al., 1951) (mg of protein $/ \mathrm{ml}, 0-\ldots-O)$. The ratio: $0 . \mathrm{D} . / \mathrm{mg}$ of protein $\left(\mathrm{O}_{-}-\mathrm{O}^{-}\right)$expresses the specific activity of $N$-acetyl- $\beta$-D-glucosaminidase. Note the virtually identical position in the gradients of the mitochondrial (MIT) and lysosomal (LY) fractions of two distinct peaks, $A$ and $B$.

enrichment of lysosomes was in peak LY $A$ (Fig. 4, rightpanel)and appeared in Fig. 5 $\mathrm{C}$ as a field in which virtually all of the intact membrane-bounded electron-denseparticles could be identified as lysosomes and derivative structures (KOENIG, 1969).

\section{DISCUSSION}

Using $p$-nitrophenyl- $N$-acetyl- $\beta$-D-glucosaminide and -galactosaminide as substrates, with rat brain as the source of $N$-acetylhexosaminidase, FroHWEIN and GATT (1967) demonstrated that the hydrolysis of the latter compound proceeded at about one-eighth of the rate of the former compound. More recently, BOSMANN and HEMSWORTH (1970) observed a similar disparity in the utilization of the two compounds by guinea pig brain. These latter authors also observed species-dependent glucosaminide: galactosaminide hydrolysis ratios ranging from a low value of 2.9 (with crude guinea pig synaptosomes) to a high value of 12.2 (when purified rat synaptosomes were used). The existence of a fraction highly active toward the glucosaminide but totally devoid of activity toward the galactosaminide has also been reported. SHUTER, ROBINS, FREEMAN and JUNGalwala (1970) recently noted a preferential utilization of the glucosaminide by preparations of rat and rabbit cerebellar white matter, granular and molecular layers. Our results (Table 1) show that immature and adult cortical neuronal cell bodies and glial cells display the same kind of preference with the result, under the conditions of our tests, that there was a constant glucosaminide:galactosaminide preference ratio of about 10 . Our additional finding of 20 -fold lower levels of $a-$ mannosidase than of $N$-acetyl- $\beta$-D-glucosaminidase activity (Table 1) agrees with 
the results of BOSMANN and Hemsworth (1970) and of QuARLES and BRADY (1970) in qualitative but not in quantitative terms. The quantitative discrepancy between the various sets of results is probably the consequence of the differences in $\mathrm{pH}$ used in the $a$-mannosidase assay by the three groups of investigators, namely, $\mathrm{pH} 4 \cdot 2$ by Bosmann and Hemsworth (1970), pH 6.0 by Quarles and Brady (1970) and pH 5.0 in the present study.

Recently the developmental profile of brain hexosaminidase has been examined by several workers. "Except for a small increase at 20 days", QuARLES and BRADY (1970) noted rather constant levels of specific activity for $N$-acetyl- $\beta$-D-glucosaminidase in 1- to 90-day-old rat brains. VERITY, BROWN and REITH (1968) prepared high-speed supernatant fractions from homogenates of mouse cerebral hemispheres in $0.25 \mathrm{M}$ sucrose and determined the specific activity of $N$-acetyl- $\beta$-D-glucosaminidase over an age period of about 500 days, with naphthyl- $N$-acetyl- $\beta$-D-glucosaminide as substrate; they noted its rapid rise between days 8 and 10 and constant levels thereafter. ROUKEMA VAN DEN RIJNDEN, HeIJMAn and VAN DER Berg (1970) used $N$-acetyl- $\beta$-D-galactosaminide as substrate and noted a sharp but shortlived surge in its hydrolysis by homogenates of whole rat brain during the second and third post-natal weeks; rates of hydrolysis returned to about 75 per cent of maximal levels thereafter for the duration of the 5-month experimental period. Finally, in a developmental study of human brain $N$-acetyl- $\beta$-D-glucosaminidase, HARzER and SANDHOFF (1971) reported a slow but sustained increase beginning 15-25 weeks prenatally and extending to age $81 \mathrm{yr}$, whereas OOHMAN and SVENNERHOLM (1971) noted high activities in fetal brains, decreased activity in young $(0-10 \mathrm{yr})$ brains and a slight increase in the adult human brain.

Our results shown in Fig. $2 \mathrm{~A}$ and Table 2 demonstrate that in rat brain the specific activity of neuronal $N$-acetyl- $\beta$-D-glucosaminidase rises sharply during the first 18 days of post-natal life and decreases somewhat subsequently. Our data also show that the specific activity of the glucosaminidase increased simultaneously with its enrichment in the 3 particulate fractions (Table 2) and its impoverishment in the nuclear fraction; thus, whereas the mitochondrial, lysosomal and microsomal fractions accounted for 49.9 per cent of the total recovered activity at age 3 days, their share increased to and levelled off at about 65 per cent by day 8 . Another significant finding was the invariably minor contribution of any soluble glucosaminidase component to the total activity, an observation which strongly suggests that the competence for the incorporation of the glucosaminidase protein into a fully functional lysosomal particle is acquired very early in neuronal development, thus enabling the neuron in the 3-dayold brain to adequately regulate the extremely rapid turnover of macromolecules taking place in its cell body (JOHNSON and SELLINGER, 1972) by a proper adjustment of the balance between the synthetic (ribosomal) and the degradative (lysosomal) events.

The mitochondrial marker enzyme used in our study develops out of step with the lysosomal $N$-acetyl- $\beta$-D-glucosaminidase, reaching maximal specific activity levels earlier, namely at about 12 days post-natally (Fig. 2 B). Our observation of an abrupt drop in the specific activity of this enzyme [also seen with the glial enzyme (SELLINGER and SANTIAGo (1972)] differs from the findings of BANIK and Davison (1969), who noted a rather steady increase of its specific activity in whole brain homogenates and in purified mitochondrial fractions from day 12 onward. 


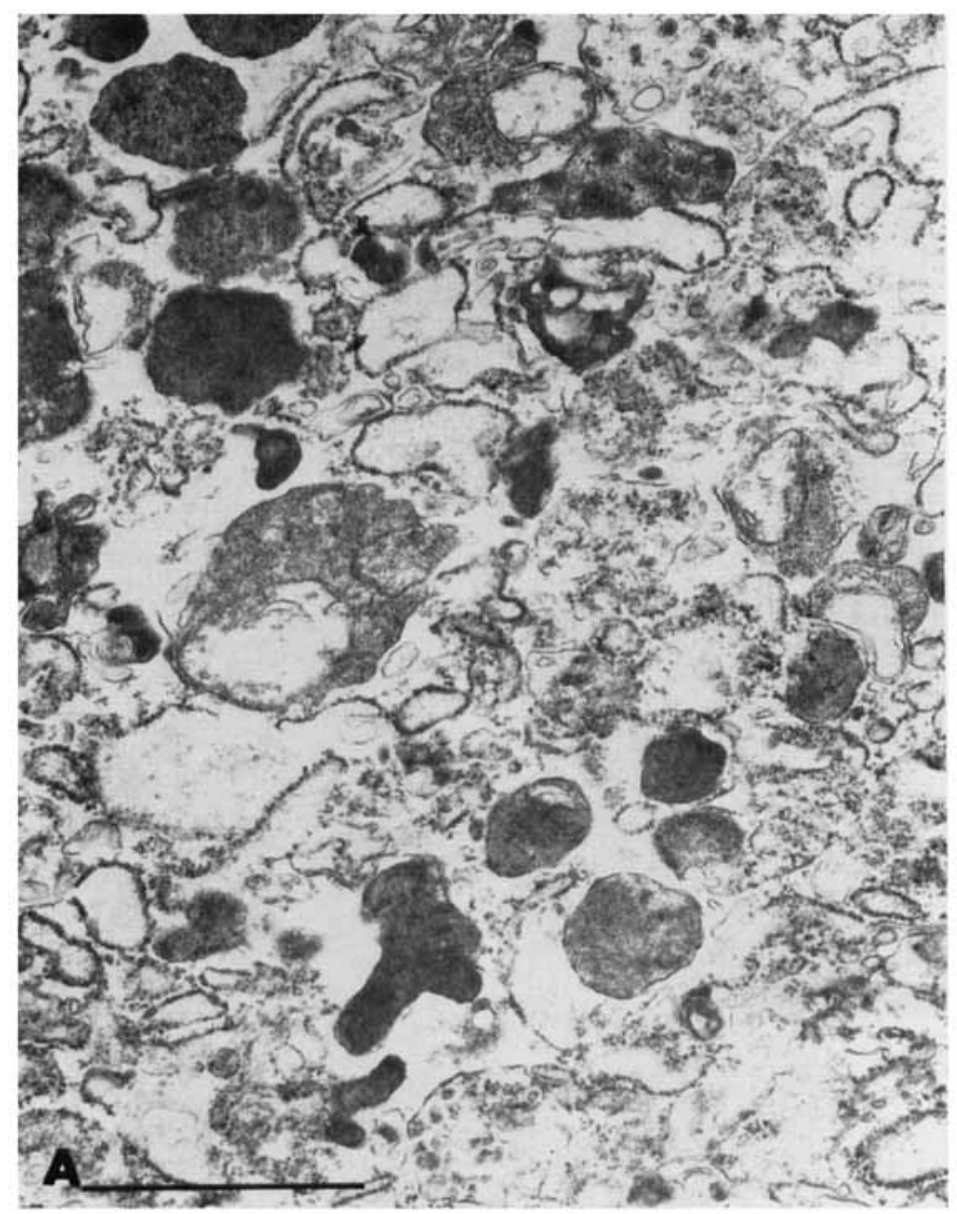

A. Peak MIT $A$ of Fig. 4, left panel.

FiG. 5.-Electron micrographs of the contents of gradient fractions $A$ and $B$ of Fig. 4:

Magnification: negatives $\times 10,200$; prints: $\times 26,500$. Bar $=1 \mu \mathrm{m}$. 


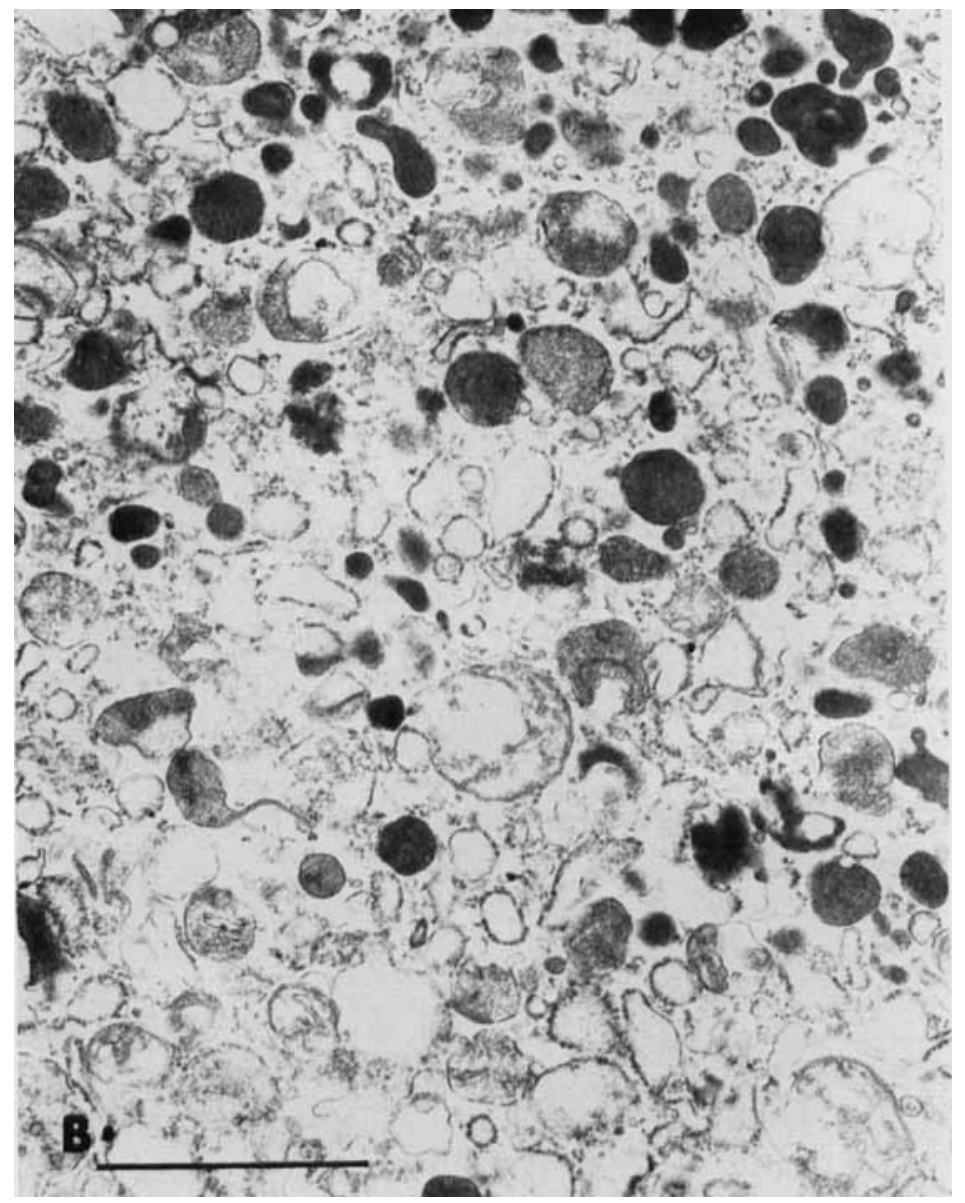

5 B. Peak MIT $B$ of Fig. 4, left panel. 


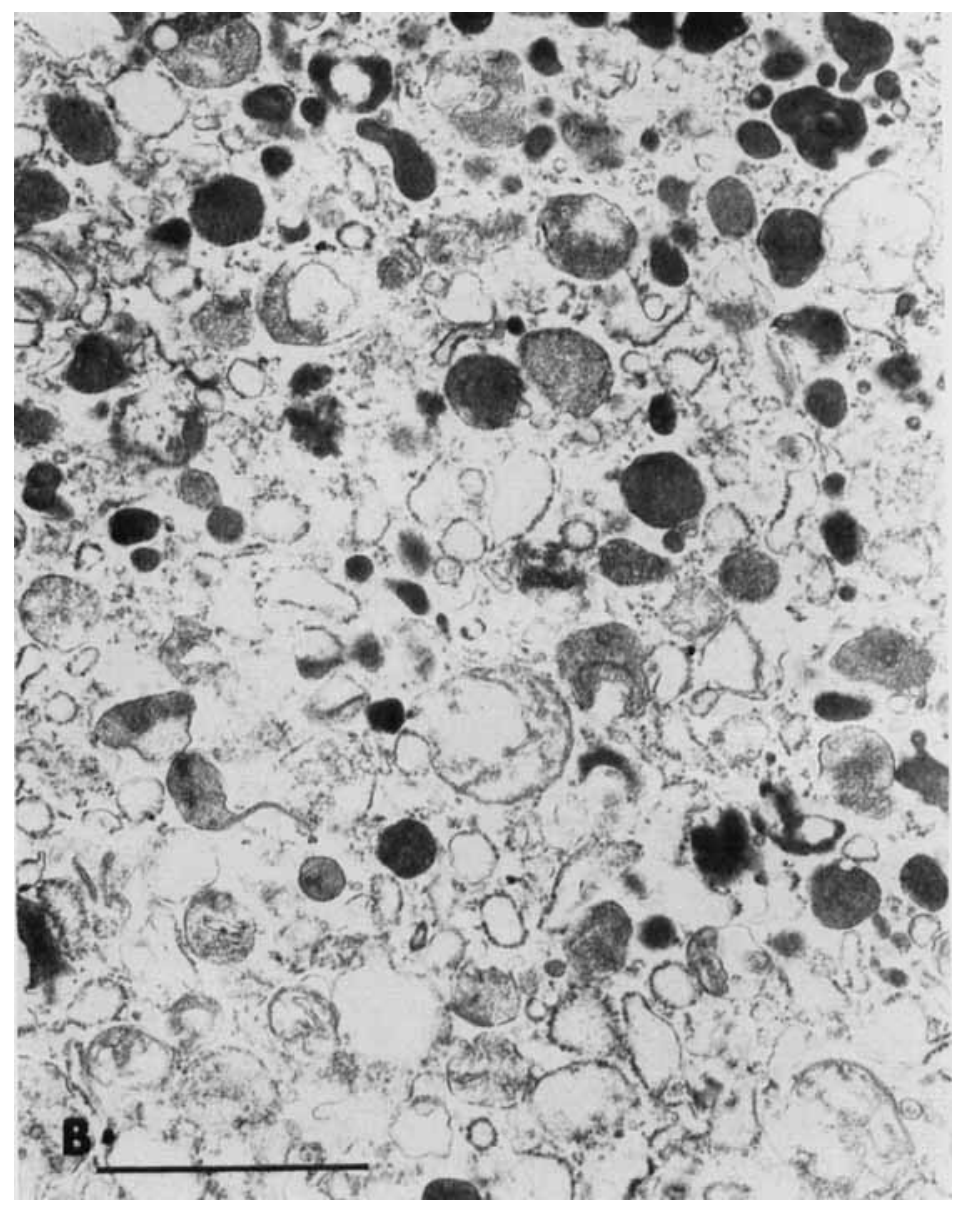

5 C. Peak LY $A$ of Fig. 4, right panel. 


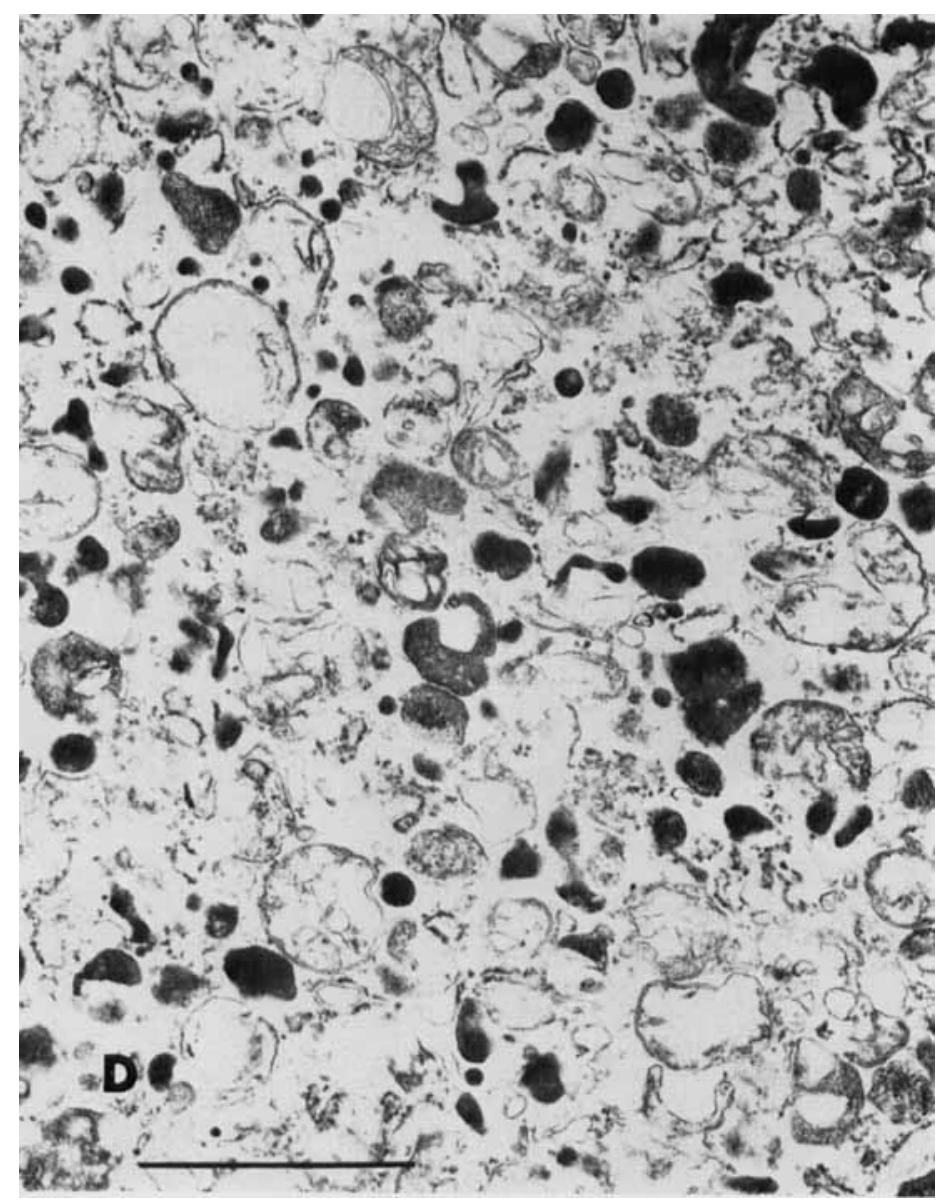

5 D. Peak LY $B$ of Fig. 4, right panel. 
Possibly the apparent discrepancy between the two sets of results may mean that the increase seen by BANIK and DAVISON (1969) relates specifically to the succinate-INToxidoreductase located in intrasynaptosomal mitochondria and not in those associated with the perikaryon. In this regard, cerebral mitochondrial cytochrome oxidase activity (EC 1.9.3.1) was recently shown to level off at about day 15 post-natally (WILsON, 1972), while the mitochondrial NADP-linked isocitrate dehydrogenase (EC 1.1.1.42) reached peak levels on post-natal day 10 but then decreased to less than 70 per cent of its maximal levels by post-natal day 20 .

Previously, Verity et al. (1968), as well as ourselves (SEllinger and NordRUM, 1969), suggested that there may be qualitative shifts in lysosomal heterogeneity during the period of cerebral maturation. Our results (Fig. 3) document the developmental course of this heterogeneity in the immature neuronal cell body by demonstrating its incipient genesis in the neurons from the 3-day-old brain (column 1; Fig. 3) and the attainment of its full expression in the neurons from the 8-day-old brain (column 2; Fig. 3). Moreover, a comparison of the gradient distribution profiles of $N$-acetyl- $\beta$-D-glucosaminidase in panels $2 \mathrm{~A}$ and $\mathbf{B}$ in comparison to those in panels $4 \mathrm{~A}$ and $\mathrm{B}$ (Fig. 3) provides additional evidence in favour of the occurrence of a developmental shift in lysosomal heterogeneity during neuronal maturation: the two-peak profile in the neurons from the 8-day-old brain converts in the neurons from the 18-day-old brain into a profile in which the lighter of the two lysosomal populations has fused with the denser one.

\section{REFERENCES}

BANiK N. L. and Davison A. N. (1969) Biochem. J. 115, 1051.

Bosmann H. B. and Hemsworth B. A. (1970) Physiol. Chem. Phys. 2, 249.

Elving P. J., Markowitz M. J. and Rosenthal I. (1956) Analyt. Chem. 28, 1179.

Fleck A. and BegG D. (1965) Biochim. biophys. Acta 108, 333.

FroHWEIN Y. Z. and GATT S. (1967) Biochemistry, Easton 6, 2775.

HARzer K. (1970) $Z$. analyt. Chem. 252, 170.

Harzer K. and Sandhoff K. (1971) J. Neurochem. 18, 2041.

Hunter G. D. and Millson G. C. (1966) J. Neurochem. 13, 375.

Idoyaga-Vargas V. and Sellinger O. Z. (1971) Trans. Am. Soc. Neurochem. 2, 89.

Johnson D. E. and Sellinger O. Z. (1971) I. Neurochem. 18, 1445.

Johnson D. E. and Sellinger O. Z. (1972) Trans. Am. Soc. Neurochem. 3, 90.

Koenig H. (1969) In Handbook of Neurochemistry (Edited by LaJTHa A.) Vol. 2, p. 255. Plenum Press New York.

Lowry O. H., Rosebrough W. J., Farr A. L. and Randall R. J. (1951) J. biol. Chem. 193, 265.

ÖHMAN R. and SVENNERHOLM L. (1971) J. Neurochem. 18, 79.

OKADA S. and O'Brien J. S. (1969) Science, N.Y. 165, 698.

Patel A. and Koenig H. (1971) Abstr. Commun., 3rd Int. Meet., Int. Soc. Neurochem. (Budapest), p. 291.

Quarles R. H. and BRADY R. O. (1970) J. Neurochem. 17, 801.

Robinson D. and StiRling J. L. (1968) Biochem. J. 107, 321.

Roukema P. A., van den Eijnden D. H., Heijlman J. and van der Berg G. (1970) FEbS Letters 9, 267.

SANDHOFE K. (1969) FEBS Letters 4, 351.

Sellinger O. Z., Azcurra J. M., Johnson D. E., Ohlsson W. G. and Lodin Z. (1971a) Nature New Biol., Lond. 230, 253.

Sellinger O. Z., Azcurra J. M., Ohlsson W. G., Kohl H. H. and Zand R. (1972) Fedn Proc. Fedn. Am. Socs. exp. Biol. 31, 160.

Sellinger O. Z. and de Balbian Verster F. (1962) J. biol. Chem. 237, 2836.

Sellinger O. Z. and HiatT R. A. (1968) Brain Res. 7, 191.

Sellinger O. Z., Lodin Z. and Azcurra J. M. (1972) Brain Res. 42, 159.

Sellinger O. Z. and Nordrum L. M. (1969) J. Neurochem. 16, 1219.

Sellinger O. Z., Nordrum L. M. and Idoyaga-Vargas V. (1971b) Brain Res. 26, 361. 
Sellinger O. Z., Ohlsson W. G., Frankel A. J., Azcurra J. M. and Petiet P. D. (1971c) J. Neurochem. 18, 1243.

Sellinger O. Z., Rucker D. L. and de Balbian Verster F. (1964) J. Neurochem. 11, 271.

Sellinger O. Z. and Santiago J. C. (1972) Neurobiology (Copenhagen), in press.

Sellinger O. Z., Santiago J. C., Idoyaga-Vargas V., Medzihradsky F. and Nandhasri P. (1971d) Abstr. Commun., 3rd Int. Meet., Int. Soc. Neurochem. (Budapest) p. 384.

Shuter E. R., Robins E., Freeman M. L. and Jungalwala F. B. (1970) J. Histochem. Cytochem. 18, 271.

Suzuki Y., JAcob J. C., Suzuki K., Kutty K. M. and Suzuki K. (1971) Neurology, Minneap. $21,313$.

SuzUKI Y. and Suzuki K. (1970) Neurology, Minneap. 20, 848.

Tallman J. F. JR., BRady R. O. and Suzuki, K. (1971) J. Neurochem. 18, 1775.

Verity M. A., Brown W. J. and ReITH A. (1968) J. Neurochem. 15, 69.

WILSON J. E. (1972) J. Neurochem. 19, 223.

Young E. P., Ellis R. B., Lake B. D. and Patrick A. P. (1970) FEBS Letters 9, 1. 